\title{
Introduction to Against the "Death" of the Discipline of Comparative Literature
}

\author{
Shunqing Cao \\ Sichuan University
}

Follow this and additional works at: https://docs.lib.purdue.edu/clcweb

Part of the Comparative Literature Commons

Dedicated to the dissemination of scholarly and professional information, Purdue University Press selects, develops, and distributes quality resources in several key subject areas for which its parent university is famous, including business, technology, health, veterinary medicine, and other selected disciplines in the humanities and sciences.

CLCWeb: Comparative Literature and Culture, the peer-reviewed, full-text, and open-access learned journal in the humanities and social sciences, publishes new scholarship following tenets of the discipline of comparative literature and the field of cultural studies designated as "comparative cultural studies." Publications in the journal are indexed in the Annual Bibliography of English Language and Literature (Chadwyck-Healey), the Arts and Humanities Citation Index (Thomson Reuters ISI), the Humanities Index (Wilson), Humanities International Complete (EBSCO), the International Bibliography of the Modern Language Association of America, and Scopus (Elsevier). The journal is affiliated with the Purdue University Press monograph series of Books in Comparative Cultural Studies. Contact: <clcweb@purdue.edu>

\section{Recommended Citation}

Cao, Shunqing. "Introduction to Against the "Death" of the Discipline of Comparative Literature." CLCWeb: Comparative Literature and Culture 19.5 (2017): <https://doi.org/10.7771/1481-4374.3118>

The above text, published by Purdue University Press @Purdue University, has been downloaded 323 times as of $11 /$ $07 / 19$.

This document has been made available through Purdue e-Pubs, a service of the Purdue University Libraries. Please contact epubs@purdue.edu for additional information.

This is an Open Access journal. This means that it uses a funding model that does not charge readers or their institutions for access. Readers may freely read, download, copy, distribute, print, search, or link to the full texts of articles. This journal is covered under the CC BY-NC-ND license. 


\title{
PURDUE
}

\author{
UNIVERSITY PRESS <http://www.thepress. purdue.edu>
}

\section{CLCWeb: Comparative Literature and Culture}

ISSN 1481-4374 <http://docs.lib.purdue.edu/clcweb> Purdue University Press @Purdue University

CLCWeb: Comparative Literature and Culture, the peer-reviewed, full-text, and open-access learned journal in the humanities and social sciences, publishes new scholarship following tenets of the discipline of comparative literature and the field of cultural studies designated as "comparative cultural studies." In addition to the publication of articles, the journal publishes review articles of scholarly books and publishes research material in its Library Series. Publications in the journal are indexed in the Annual Bibliography of English Language and Literature (Chadwyck-Healey), the Arts and Humanities Citation Index (Thomson Reuters ISI), the Humanities Index (Wilson), Humanities International Complete (EBSCO), the International Bibliography of the Modern Language Association of America, and Scopus (Elsevier). The journal is affiliated with the Purdue University Press monograph series of Books in Comparative Cultural Studies. Contact: <clcweb@purdue.edu>

Volume 19 Issue 5 (December 2017) Article 1 Shunqing Cao,

"Introduction to Against the 'Death' of the Discipline of Comparative Literature" <http://docs.lib.purdue.edu/clcweb/vol19/iss5/1>

Contents of CLCWeb: Comparative Literature and Culture 19.5 (2017) Special Issue Against the "Death" of the Discipline of Comparative Literature Ed. Shunqing Cao

<http://docs.lib.purdue.edu/clcweb/vol19/iss5/> 


\section{Shunqing CAO}

\section{Introduction to Against the "Death" of the Discipline of Comparative Literature}

Alongside the development of Comparative Literature are constant voices of announcing its crisis. The identity of the discipline seems always doubt. In 1958, witnessing Comparative Literature having been bogged in the binary mode of influence study which focuses on rapport de fait instead of interliterary comparison, the scholar René Wellek presented a paper titled "The Crisis of Comparative Literature" at the second conference of the International Comparative Literature Association, which inaugurates a trend of pessimistic diagnosis of Comparative Literature during the past five decades. For Wellek and many others, Comparative Literature is not legitimate because of "the fact that it has not been able to establish a distinct subject matter and a specific methodology" (282).

Facing the crisis of the discipline, many American comparatists adopted a view of interdisciplinary comparison. Henry H.H. Remak, for example, offered a well-received definition of Comparative Literature as "the comparison of one literature with another or others, and the comparison of literature with other spheres of human expression" (3). Endeavors such as this seem to have relieved the crisis, but as a matter of fact, also pushed the frontier to an unexpectedly large extent. The crisis still remained. In 1993, the well-known comparatist Susan Bassnett even declared that "today, Comparative Literature is in one sense dead" (47). Ten years later Gayatri Chakravorty Spivak reiterated, with a stronger voice this time, the "death" of Comparative Literature as a discipline, describing it as having "the last gasp of a dying discipline" (xii). For them, translation studies, intercultural studies, or area studies would be the better substitutes of Comparative Literature.

While the crisis of Comparative Literature might be lingering for the past decades, the knell of the discipline is far from being clear. On the contrary, Comparative Literature is right now in its booming period in many parts of the world like India, China, Japan, Brazil, Hungary, Spain, etc. With a stance of resisting Eurocentrism, West-centrism, or center-peripheral dichotomy, comparative enterprises in these areas represent new explorations of subject matter and methodology-two fundamentals of Comparative Literature. Recent years have witnessed vigorous ramifications extended from the discipline of Comparative Literature which have reversely strengthened Comparative Literature per se: translation studies, comparative cultural studies, area studies, world literature, variation studies, etc.

As a matter of fact, there always exists an optimistic view on the prospect of Comparative Literature especially when it takes strides along the path of interdisciplinarity or "crossing borders". This is why Haun Saussy declares the "triumph of Comparative Literature" in the 2004 state report of the discipline of Comparative Literature published by ACLA, and Rey Chow defines Comparative Literature as a "discipline of tolerance", a discipline made up of "a loose discourse network sprouting from an incessant proliferation, intermingling, and hybridization of subjects " (24).

Therefore, it is significant to propose this thematic issue to consider the following questions: how can we understand correlations between the "death" (or "crisis") versions and the new paradigms advocated or practiced by some modern comparatists: cultural relativism (Fokkema), East/West studies (Miner), postcolonial theory (Said), translation study (Venuti), comparative cultural studies (Tötösy de Zepetnek), world literature (Damrosch), variation studies (Cao), among many others? In what contexts are the pessimistic voices often articulated and what we can draw from the past in order to deal with new challenges and crises faced by comparatists at present? How to make use of the pessimistic voices propel the development of Comparative Literature as a discipline worldwide in general and more importantly for our part, as a discipline in China?

Against the "Death" of the Discipline of Comparative Literature includes the following articles:

In "The Theoretical Basis and Framework of Variation Theory"

<http://docs.lib.purdue.edu/clcweb/vol19/iss5/2> Shunqing Cao and Zhoukun Han provide new reflection of current international comparative literature studies. By demonstrating what variation theory can do and what can we get from it, they claim that variation theory might provide a possible solution for the current discipline crisis, and pave a way for the future direction of this discipline.

In "Terminology Translation and the Rebirth of Comparative Literature in China"

<http://docs.lib.purdue.edu/clcweb/vol19/iss5/3> Peina Zhuang and Huan Pi discuss terminology translation during the rise of Comparative Literature in China and divide the problems in status quo into three aspects: the lack of unity, standardization, and accuracy in terminology translation. They argue that more attention should be given to the scholarship combined with concrete empirical research such as dictionary compilation, and standardization of translation norms.

In "Problem-based Variations in Teaching Stephen Dobyns's 'Kansas' in China" 
<http://docs.lib.purdue.edu/clcweb/vol19/iss5/4> Tao Zou and Hong Zeng analyze the different variations in the authors' experience of teaching foreign literature in China and the positive results of adopting variation theory in comparative literature, that is, making the teaching of foreign literature a stage for inspiring cross-cultural communication and creativity.

In "Could World Literature be the Future of Comparative Literature?"

<http://docs.lib.purdue.edu/clcweb/vol19/iss5/5> Jing Zhou analyzes the feasibility and validity of world literature as the future of Comparative Literature and concludes that world literature could not be the future of Comparative Literature due to its confinement to the still prevailing Euro-Us centralism in its studies.

In "Rebirth of Comparative Literature in China from the Perspective of Medio-translatology"

<http://docs.lib.purdue.edu/clcweb/vol19/iss5/6> Wei Guo examines the "rebirth" of Comparative Literature in China from the development of medio-translatology here. By differentiating "translation studies" and "medio-translatology", he reexamines the role and position of translation in Comparative Literature by making translation an independent branch in this discipline. Thus Guo addresses the ending of the longstanding confusions in translation under medio-translatology and translation studies and certain controversial phenomena in translation.

In " Reconsiderations on the Crises on Comparative Literature Study"

<http://docs.lib.purdue.edu/cl cweb/vol19/iss5/7> Jie Lu represents a retrospect of the three crises in comparative literature and points out the underlying causes for these crisis: that is, three misunderstandings of "comparative literature", that is, "narrowing," "overgeneralization," and "trivialization," all of which are analyzed in detail in the authors' argumentation.

In "Another Argument on the "Crisis Said" of Comparative Literature"

<http://docs.lib.purdue.edu/clcweb/vol19/iss5/8> Ping Du examines the "death said" predicts and the "rebirth" of Comparative Literature in the Age of Multiculturalism. She argues that the way out of the nightmare of "crisis" is not world literature as advocated but the Chinese School and its Variation Studies which are the future of Comparative Literature.

In "Reflections on the Crisis of Comparative Literature in the Contemporary West"

<http://docs.lib.purdue.edu/clcweb/vol19/iss5/9> Zhoukun Han and Wen Quan discuss the Crisis of Comparative Literature in the contemporary West and ascribe the last straw to the shift from literary comparison to cultural study in Comparative Literature. They argue that the Chinese scholars's response such as cross-civilization studies and variation theory could be inspiring promises for a new theoretical construction for comparative literature.

In "The Futures of Comparative Literature Envisioned by Chinese Comparatists"

<http://docs.lib.purdue.edu/clcweb/vol19/iss5/10> Sheng Meng and Yue Chen discuss the four representative opinions of Chinese scholars in response to the crisis of Comparative Literature and point their respective role in shaping the future of Comparative Literature development both in China and the world at large.

In "The Significance of the Variation Theory in Cross-Cultural Communication"

<http://docs.lib.purdue.edu/clcweb/vol19/iss5/11> Yi Wan examines two key concepts in Variation Theory, that is, variability and heterogeneity combined with their significance in cross-civilization studies in Comparative Literature.

Against the "Death" of the Discipline of Comparative Literature includes a "Bibliography for the Study of the" Death" of the Discipline of Comparative Literature" compiled by guest editor Shunqing Cao <http://docs.lib.purdue.edu/clcweb/vol19/iss5/12>.

\section{Works Cited}

Bassnett, Susan. Comparative Literature: A Critical Introduction. Oxford: Blackwell, 1993.

Chow, Rey. "A Discipline of Tolerance." A companion to Comparative Literature. Ed. Ali Behdad and Dominic Thomas. Oxford: Wiley-Blackwell, 2011.

Remak, Henry H.H. "Comparative Literature: Its Definition and Function." Comparative Literature: Method and Perspective. Ed. Newton P. Stallknecht and Horst Frenz. Carbondale: Southern Illinois UP, 1961.

Saussy, Haun, ed. Comparative Literature in an Age of Globalization. Baltimore: Johns Hopkins UP, 2006.

Spivak, Gayatri Chakravorty. Death of a Discipline. New York: Columbia UP, 2003.

Wellek, René. "The Crisis in Comparative Literature." Concepts of Criticism. Ed. Stephen Nichols. New Haven: Yale UP, 1963.

Guest editor's profile: Shunqing Cao teaches literary theory and comparative literature at Sichuan University and Beijing Normal University. His interests in scholarship include classic Chinese literature theory, comparative literature, comparative poetics, and world literature. In addition to numerous articles and books in Chinese and English, 
Shunqing Cao, "Introduction to Against the 'Death' of the Discipline of Comparative Literature"

CLCWeb: Comparative Literature and Culture 19.5 (2017): http://docs.lib.purdue.edu/clcweb/vol19/iss5/1

page 4 of 4

Special Issue Against the "Death" of the Discipline of Comparative Literature. Ed. Shunqing Cao

his recent book publications include The Variation Theory of Comparative Literature (2013) and the edited volume 中外文论史 (History of Chinese and Western Literary Theory) (2012). E-mail: <caosq@scu.edu.cn> 